\section{Potential Sources of Resistance to Broad Mites (Polyphagotarsonemus latus) in Watermelon Germplasm}

\author{
Chandrasekar S. Kousik ${ }^{1}$ \\ U.S. Department of Agriculture, Agricultural Research Service, U.S. \\ Vegetable Laboratory, 2700 Savannah Highway, Charleston, SC 29414 \\ B.M. Shepard and Richard Hassell \\ Clemson University, Coastal Research and Education Center (CREC), 2700 \\ Savannah Highway, Charleston, SC 29414
}

\begin{abstract}
Amnon Levi and Alvin M. Simmons
U.S. Department of Agriculture, Agricultural Research Service, U.S. Vegetable Laboratory, 2700 Savannah Highway, Charleston, SC 29414
\end{abstract}

Additional index words. host plant resistance, breeding, Citrullus spp., plant introduction

\begin{abstract}
Two hundred nineteen U.S. plant introductions (PI) belonging to the watermelon core collection were evaluated for broad mite, Polyphagotarsonemus latus (Banks), infestation and injury that occurred naturally in a field planting. Of the 219 PIs, nine $(4 \%)$ had no visible broad mite injury in the field compared with a commercial cultivar, 'Mickey Lee', which was severely injured. Injury mainly occurred on the growing terminals and the tender apical leaves. The growing terminals and the apical leaves were bronzed, grew poorly and, in some cases, they were distorted and curled upward. Broad mites were extracted by washing the growing terminals of 22 selected PIs with boiling water and counting the mites under a stereomicroscope. 'Mickey Lee' had more broad mites on growing terminals compared with some of the PIs with no visible injury. Fourteen selected PIs were further evaluated in the greenhouse to confirm their resistance by artificially infesting them with broad mites that had been cultured on susceptible watermelon plants. PIs in accessions belonging to Citrullus lanatus var. lanatus (PI 357708), Citrullus lanatus var. citroides (PI 500354), Citrullus colocynthis (PI 386015, PI 386016, PI 525082), and Parecitrullus fistulosus (PI 449332) had significantly lower broad mite injury ratings and counts compared with 'Mickey Lee' and other susceptible PIs. Broad mites have not been reported on watermelons in the United States before; however, it can emerge as a serious pest. The previously mentioned accessions can serve as potential sources of broad mite resistance for use in breeding programs aimed at enhancing pest resistance in watermelon.
\end{abstract}

Broad mite [Polyphagotarsonemus latus (Banks) (Acari: Tarsonemidae)], as the scientific name suggests, is a major polyphagous pest of many important agricultural crops, particularly vegetables. Broad mites have been found on hosts belonging to at least 60 plant families, including Cucurbitaceae (Bassett, 1981; Gerson, 1992; Goff, 1987). In particular, cucumbers are known to be highly susceptible to mite infestations (Bassett, 1981; Grinberg et al., 2005). On cucurbits, the mites are generally found on the apical

\footnotetext{
Received for publication 22 Dec. 2006. Accepted for publication 19 Feb. 2007.

We thank Dr. Beverly Gerdeman for identification of broad mites and helpful discussions. We also acknowledge the technical assistance of William Cook, J. Dufault, R. Carrington, and M. Schaffer in conducting the field and greenhouse experiments. Mention of a trademark name or proprietary product does not constitute a warranty or guarantee by the U.S. Department of Agriculture nor does it imply exclusion of other products that may also be suitable.

${ }^{1}$ To whom reprint requests should be addressed; e-mail shaker.kousik@ars.usda.gov.
}

parts of the plant and the undersides of young leaves (Bassett, 1981). The dramatic effects of broad mite infestations and feeding becomes evident by the appearance of tissue damage and changes in plant morphology and physiology. Infested plants show growth inhibition and a decrease in leaf numbers and area (Grinberg et al., 2005). Although broad mites feed mainly on the epidermis of the plant parts, structural aberrations occur throughout the tissue (Grinberg et al., 2005). In cucurbits, the young apical leaves and growing tips are severely damaged and the plant growth is inhibited (Bassett, 1981; Grinberg et al., 2005). The injury incited by broad mites is thought to be the result of toxins that are secreted during feeding and continue even after the mites have been killed by a pesticide (Bassett, 1981; Gerson, 1992). In most vegetable crops, the use of acaricides is the main control tactic for managing broad mites. However, many of the pesticides that are used to manage mites are also harmful to the beneficial parasitoids and predators (Lazarre and Gerling, 1993; Simmons and Jackson, 2000). Thus, identifying and devel- oping host-plant resistance to pests such as mites is more sustainable and fits well into an overall integrated pest management (IPM) strategy for broad mite control.

Watermelon (Citrullus lanatus var. lanatus) is an important vegetable crop in the United States with a total harvested area of 55,200 ha. The states with the largest watermelon acreage are Florida (10,500 ha), Georgia $(10,100)$, Texas (9000), California (5250), Indiana (2950), South Carolina (2800), and North Carolina (2450) (U.S. Department of Agriculture, 2006). Many different pests impact watermelon production in these states (Webb et al., 2001). Broad mites have been reported to attack watermelons in South America before (Zhang, 2003), and we frequently observe them on watermelons grown in our greenhouse (personal observations). Broad mites are not generally considered a major pest of watermelon in production fields. However, with the continued introduction of new watermelon varieties on a consistent basis, broad mites could potentially become an important economic pest. Several researchers have considered broad mites to be an emerging pest (Gerson, 1992; Jones, 1988). Interestingly, the present field study was primarily designed to identify sources of resistance to watermelon fruit rot incited by Phytophthora capsici. However, in early July when the conditions were favorable, we observed severe broad mite infestations on most of the watermelon plants in the field. Thus, the objective of the present study was to identify and confirm potential sources of resistance to broad mites in watermelon PIs. The information presented in this article and the availability of sources of resistance to broad mites and other pests will be useful to breeders and others working with watermelons in development of resistant varieties. Although resistance to spider mites has been reported in watermelons (Dhooria et al., 1987; Lopez et al., 2005; Mansour and Karchi, 1994; Tulisalo, 1972), we are not aware of any reports of resistance to broad mites in watermelon.

\section{Materials and Methods}

Plant material and field plots. Seeds of all of the watermelon PIs in the core collection (254 PI) were obtained from the USDA-ARS Plant Genetic Resources Conservation Unit (Griffin, GA). Seeds of individual PIs were planted in 50-cell Jiffy trays filled with metromix (Sun Gro Horticulture, Bellevue, WA) and allowed to grow in a greenhouse. Day and night temperatures in the greenhouse were 28 and $21^{\circ} \mathrm{C}$, respectively. Fourweek-old plants of watermelon PIs were planted during the last week of Apr. 2006 on 1.1-m wide raised beds covered with white plastic mulch. Plants were spaced $46 \mathrm{~cm}$ apart with a single row of plants in the center of each bed. Spacing between beds was $4.3 \mathrm{~m}$. Standard fertilization and weed management practices were followed (Sanders, 2005). Plants were drip-irrigated when needed. Five plants of each PI were planted 
per plot. This trial was not replicated. In early July 2006, a severe broad mite infestation was observed on most of the PIs. Therefore, we rated the watermelon germplasm for mite injury on a 0 to 4 scale, in which $0=$ no injury observed on any of the growing terminals in the plot; 1 = very low, at least one growing terminal in the plot showing mite injury but less than $10 \%$ of the terminals showing injury; $2=$ slight injury with $\approx 25 \%$ of the terminals showing injury; $3=$ moderate injury with $\approx 50 \%$ of growing terminals showing mite injury; and $4=$ severe injury with more than $50 \%$ of the terminals showing broad mite injury.

Mite populations on selected PIs in the field. Five growing terminals from each of the plots that had been rated 0 (or in some cases rated 1 with only one or two terminals in the plot having injury) were randomly excised, placed in individual zip-lock plastic bags, and transported to the laboratory in a cooler. Similarly, growing terminals from plots of the commercial variety 'Mickey Lee', which was susceptible to broad mite injury and was severely injured, were also collected. Plots of 'Mickey Lee' had been planted randomly in each of the beds to monitor for $P$. capsici infection levels, and thus this variety also served as our control to monitor broad mite injury and infestation levels. The growing terminals were cut to $7.62 \mathrm{~cm}$ ( 3 inches) and inserted into $25-\mathrm{mL}$ glass test tubes. Ten milliliters of boiling water was poured into each test tube containing the growing terminals. The tubes were capped and vortexed at the highest setting twice for $15 \mathrm{~s}$ each time. The dislodged mites and eggs along with the water were poured into $10-\mathrm{cm}$ sterile plastic Petri dishes. Total numbers of mites, including adults, nymphs, and eggs, were counted using a stereomicroscope.

Evaluation of selected PIs in the greenhouse. Several experiments were conducted to confirm the resistance of selected PIs that had been resistant to broad mite infection in the field. Seedlings of these selected PIs were planted in 50-cell seedling trays filled with Jiffy mix. Seedlings were treated with the insecticide Admire Pro (a.i.: imidacloprid, $7 \mathrm{~g} / 10,000$ plants; Bayer Crop Science, Research Triangle Park, NC) to prevent whitefly infestations, and then they were placed in isolated cages (Bug-Dorm, Bioquip Products, Rancho Dominguez, CA), which had a fine mesh covering. Four-weekold seedlings were used in this experiment. Broad mite-infested growing terminals with a rating of 6 or 7 on the 1 to 9 scale described subsequently were randomly obtained from the plots of 'Mickey Lee' that were planted throughout the field. These growing terminals obtained from the field were placed on top of each seedling. There were five replications of a single seedling for each PI selected. Fifteen days later, growing terminals for each PI were rated on a 1 to 9 scale for levels of broad mite injury in which $1=$ no visible injury on the growing terminals and terminals lush and green and branching; $2=$ $1 \%$ to $3 \%$ injury very slight browning of tendrils and some tips of leaves; $3=4 \%$ to $10 \%$ mite injury; $4=11 \%$ to $25 \%$, partial bronzing of some of terminal and young leaf just below the terminal showing some injury; $5=26 \%$ to $35 \% ; 6=36 \%$ to $50 \%$ injury; $7=$ $51 \%$ to $65 \%$, most of growing terminal bronzed with very few visible hairs and young leaf just below the terminal necrotic and leaves severely distorted and bronzed; 8 $=$ greater than $65 \%$, severe broad mite injury seen with most of the growing terminal bronzed, tips hard and necrotic, and no leaves present below the growing terminal; and $9=$ growing terminals dead.

Broad mite culture. Broad mites were cultured on 4-week-old seedlings of 'Mickey Lee' or PI 392291 (susceptible to broad mites) grown in Bug-Dorms similar to that described by Palevsky et al. (2001) on potato foliage. However, we also treated all the seedlings with Admire Pro (a.i.: imidacloprid) as described previously to prevent whitefly and aphid infestations.

Evaluation of mite populations on selected PI in the greenhouse. Four-weekold seedlings of select PIs grown in Jiffy pots were transplanted into large plastic pots (11 $\mathrm{L}, 30-\mathrm{cm}$ diameter). All plants were treated with Marathon 1\% G (Olympic Horticultural Products, Mainland, PA), a granular formulation of imidacloprid to prevent whitefly infestations. A single plant of individual PIs was planted in each pot and the pots were randomly placed on greenhouse benches to create a completely randomized design. Plants were maintained in a greenhouse at 28 and $21^{\circ} \mathrm{C}$ for day and night temperatures, respectively. Two weeks after transplanting growing terminals of 'Mickey Lee', seedlings from broad mite culture with $\approx 66$ mites per $3.88 \mathrm{~cm}$ of growing terminals were placed on actively growing terminals of the selected PI. One infested 'Mickey Lee' growing terminal was placed on one growing terminal of each plant and fastened gently with a twisttie. 'Mickey Lee' plants, growing in similar large pots' were used as the susceptible control. After 2 weeks, the growing terminals were excised from the plants and brought to the laboratory to determine mite populations. Broad mites were washed and counted from 5$\mathrm{cm}$ growing terminals as described previously.

To further confirm resistance of the plants to broad mites, plants grown in large pots as described previously were infested with a much larger population of broad mites. Plants were infested when they were 10 weeks old. Severely injured growing terminals of PI 392291 , with a rating of at least $7 \approx 748$ broad mites per $3.88 \mathrm{~cm}$ ), were fastened to growing terminals of the selected PI as described previously. Three weeks after inoculation, growing terminals were excised and brought to the laboratory in individual plastic bags. Each of the growing terminals was rated for broad mite injury and mites were washed and counted as described previously. Two weeks later, we again randomly collected growing terminals from the PI, rated them, and counted mites as described previously.
Statistical analysis. All data were analyzed using the PROC GLM procedure of SAS (version 8.2; SAS Institute, Cary, NC). Because broad mites have a tendency to aggregate and the mite counts were erratic, all data were $\log$ transformed before analyses. Mean separations were done using the Waller-Duncan K-ratio $(K=100) t$ tests on the log-transformed data. However, actual mite counts are presented in the "Results" followed by letters for mean separation based on the log-transformed values. Rating data were analyzed by arcsine transforming the midpercentage point for each rating followed by PROC GLM procedure of SAS and mean separation tests. In the tables, the actual mean injury ratings (1-9) are presented followed by letters for mean separation based on the arcsine-transformed values using the using the Waller-Duncan K-ratio $(K=100) t$ tests.

\section{Results and Discussion}

The typical symptoms of broad mite infestations on cucurbits such as cucumbers include the young foliage and apical tips becoming rigid or bronzed and sometimes having a shriveled and scorched appearance (Bassett, 1981; Gerson, 1992; Grinberg et al., 2005). We observed similar symptoms on the growing terminals of watermelon plants in the field (Fig. 1). The presence of broad mites was confirmed and identified using published descriptions (Lindquist, 1986; Zhang, 2003; Beverly Gerdeman, personal communication). Furthermore, when we cultured broad mites on young watermelon plants, they also developed typical injury symptoms.

A summary of the evaluation of 219 Citrullus PI for mite injury is presented in Table 1 . A total of $\approx 250$ PIs was originally planted. However, we could record observations on mite injury on only 219 PIs, because plants of the remaining PIs died or grew poorly after transplanting. A total of nine of the 219 PIs had no visible broad mite injury. Severe broad mite infestations were observed in early July when the weather conditions were favorable. Broad mites thrive well under fairly mild and humid conditions with the maximum population growth being at $25^{\circ} \mathrm{C}$ (Jones and Brown, 1983). The temperatures in June were congenial for mite infestations. The mean temperatures for the month

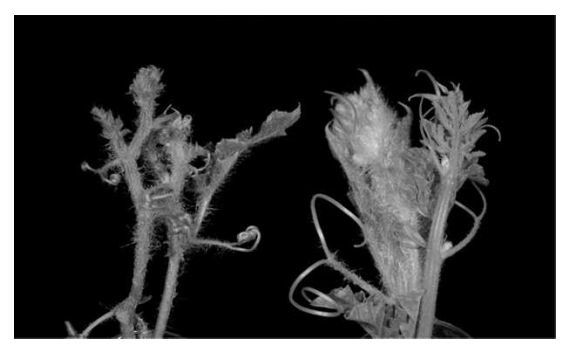

Fig. 1. Injury incited by broad mite (Polyphagotarsonemus latus) infestation on growing terminals of watermelon plants. Growing terminals on the left are injured, whereas the ones on right are healthy. 
of June and early part of July was $25.8{ }^{\circ} \mathrm{C}$ and the average relative humidity during this period was $72 \%$. We also had frequent rainfall during this period. Additionally, in close proximity, there were two pepper fields and a cowpea field where broad mite infestations were observed. Thus, it is possible that the presence of diverse kinds of watermelon PIs could have attracted the broad mites to our plots. We have regularly observed broad mite injury on watermelons in our greenhouses. However, there are few reports of broad mites on watermelons. Zhang (2003) mentioned broad mites on watermelons in South America. Other studies on evaluation of pest resistance in Citrullus and other cucurbit species have dealt with fewer numbers of accessions resulting from the difficulties in conducting large-scale evaluations in the greenhouse and the variability of infestations in the field. However, because of the severe natural infestations in the field, we were able to evaluate most of the PIs in the watermelon core collection for broad mite injury. This watermelon core collection was designed to be a representative sample of the entire PI collection, which consists of over 1700 PIs (http://www.ars-grin.gov). Thus, we were able to identify resistant PIs belonging to all the Citrullus spp.

Details of broad mite injury in the field on individual PI are presented in Table 2. Most of the PIs belonging to $C$. colocynthis were relatively tolerant to broad mite infestations with two PIs showing no visible injury in the field. PI 449332 belonging to Parecitrullus fistulosus also had no visible injury. Similarly, two C. lanatus var. citroides and four $C$. lanatus var. lanatus PIs had no visible injury in the field. The ratings for broad mite injury presented in Table 2 should be considered with caution, because, as a result of limited availability of seeds, we had one replication with five plants per PI. However, this initial field screening enabled us to narrow down our selections for further studies.

Details of broad mite counts on growing terminals of selected PIs are presented in Table 3. It has been suggested in a study on broad mites that sampling one to two apical leaves is sufficient to assess population trends (Cividanes et al., 1987). We counted mites from five growing terminals for each PI plot. Growing terminals from plants of 'Mickey Lee' collected from all the beds in the field plots had a mean of 176 mites for $7.62 \mathrm{~cm}$ (3 inches). However, mite populations ranged from eight to 448 per terminal. This variability in mite populations and the tendency of broad mites to aggregate has been previously observed in peppers (Echer et al., 2002) and other crops (Gerson, 1992). High variability was observed with most of the other PIs that had field ratings of 3 or 4 . As expected, most of the PIs that were rated 0 for broad mite injury had relatively lower numbers of mites. This was particularly true for PIs belonging to $C$. colocynthis. We also counted broad mites on some PIs that were rated 1. Typically in these cases, only one terminal for the entire plot had visible broad mite injury.

Table 1. Summary of ratings of watermelon PIs for visible broad mite injury in field plots at Charleston, SC, 2006.

\begin{tabular}{lccccrrr}
\hline & \multicolumn{5}{c}{ Number of PIs with plot ratings $^{\mathrm{z}}$} & Total \\
\cline { 2 - 6 } Citrullus spp. & 0 & 1 & 2 & 3 & 4 & 5 \\
\hline C. Colocynthis & 2 & 3 & 0 & 0 & 0 & 3 \\
P. fistulosus & 1 & 1 & 1 & 0 & 0 & 17 \\
C. lanatus var. citroides & 2 & 7 & 4 & 2 & 2 & 194 \\
C. lanatus var. lanatus & 4 & 35 & 49 & 62 & 44 & 219 \\
Total & 9 & 46 & 54 & 64 & 46 & 76 \\
\hline
\end{tabular}

${ }^{\mathrm{z}}$ Each PI plot was rated for visible broad mite injury on a 0 to 4 scale, in which $0=$ no injury observed on any of the growing terminals in the plot; $1=$ very low, at least one growing terminal in the plot showing mite injury but less than $10 \%$ of the terminals showing injury; $2=$ slight injury with $\approx 25 \%$ of the terminals showing injury; $3=$ moderate injury with $\approx 50 \%$ of growing terminals showing mite injury; and $4=$ severe injury with more than $50 \%$ of the terminals showing broad mite injury. Frequency of number of PIs in each rating category is presented.

${ }^{y}$ For more details of Citrullus spp. tested in this experiment, see the Germplasm Resources Information Network (GRIN) online database at www.ars-grin.gov.

Table 2. Broad mite (Polyphagotarsonemus latus) injury ratings for individual PIs in the watermelon core collection in field plots at Charleston, SC, 2006.

\begin{tabular}{|c|c|c|}
\hline Watermelon PIs & Citrullus group ${ }^{2}$ & Rating $(0-4)^{y}$ \\
\hline PI 386016,525082 & $\mathrm{O}$ & 0 \\
\hline PI $195927,386015,388770$ & $\mathrm{O}$ & 1 \\
\hline PI 449332 & $\mathrm{P}$ & 0 \\
\hline PI 540911 & $\mathrm{P}$ & 1 \\
\hline Grif 5602 & $\mathrm{P}$ & 2 \\
\hline PI 532624, 596671 & $\mathrm{C}$ & 0 \\
\hline PI $189225,271775,295843,482283,500354,505604,596676$ & $\mathrm{C}$ & 1 \\
\hline PI $299378,482311,532666,542123$ & $\mathrm{C}$ & 2 \\
\hline PI 482334, 596667 & $\mathrm{C}$ & 3 \\
\hline PI 271771, 296341 & $\mathrm{C}$ & 4 \\
\hline PI $254735,368526,500329,536459$ & $\mathrm{~L}$ & 0 \\
\hline PI $113326,164539,176494,179234,183933,183398,184800$ & $\mathrm{~L}$ & 1 \\
\hline PI $186489,189317,211915,254623,255622,269677,270522$ & $\mathrm{~L}$ & 1 \\
\hline PI $271778,306367,357708,257716,431579,459074,482291$ & $\mathrm{~L}$ & 1 \\
\hline PI 482323, 482343, 490377, 490386, 494527, 500301, 534533 & $\mathrm{~L}$ & 1 \\
\hline PI 535948, 536451, 549159, 559995, 595203, 612464, 612472 & $\mathrm{~L}$ & 1 \\
\hline PI $163203,164539,169289,172786,172798,174106,175102$ & $\mathrm{~L}$ & 2 \\
\hline PI 176487, 179833, 181935, 185635, 190050, 193963, 212094 & $\mathrm{~L}$ & 2 \\
\hline PI $249008,254428,269465,270545,270551,271981,271988$ & $\mathrm{~L}$ & 2 \\
\hline PI 296384, 357656, 357672, 357690, 368502, 368519, 370015 & $\mathrm{~L}$ & 2 \\
\hline PI 379237, 379249, 379256, 381725, 392291, 418762, 482266 & $\mathrm{~L}$ & 2 \\
\hline PI 482305, 482345, 491265, 494815, 500320, 507862, 512373 & $\mathrm{~L}$ & 2 \\
\hline PI 518608, 525089, 525095, 532730, 537269, 593347, 593359 & $\mathrm{~L}$ & 2 \\
\hline PI $164634,164685,169232,169237,169256,169266,171392$ & $\mathrm{~L}$ & 3 \\
\hline PI $171581,172804,174100,175654,176916,177327,182176$ & $\mathrm{~L}$ & 3 \\
\hline PI 189318, 193490, 212209, 219691, 225557, 226460, 246559 & $\mathrm{~L}$ & 3 \\
\hline PI 271132, 273479, 278008, 278028, 278044, 293766, 314236 & $\mathrm{~L}$ & 3 \\
\hline PI $344395,357727,357736,370424,370430,381704,381715$ & $\mathrm{~L}$ & 3 \\
\hline PI $381734,435991,482359,482367,482373,490384,500317$ & $\mathrm{~L}$ & 3 \\
\hline PI 500343, 505584, 506439, 512359, 512361, 512367, 512368 & $\mathrm{~L}$ & 3 \\
\hline PI $512391,512405,526235,532723,534591,537468,538888$ & $\mathrm{~L}$ & 3 \\
\hline PI 542617, 543211, 560024, 560901, 632751, Grif 5597 & $\mathrm{~L}$ & 3 \\
\hline PI 163574, 165448, 167059, 169282, 176923, 212983, 222710 & $\mathrm{~L}$ & 4 \\
\hline PI 227205, 234603, 254740, 254741, 276445, 277976, 277991 & $\mathrm{~L}$ & 4 \\
\hline PI 278020, 279461, 306782, 307750, 345545, 356787, 357750 & $\mathrm{~L}$ & 4 \\
\hline PI 378612, 430615, 470249, 476325, 482272, 482284, 487476 & $\mathrm{~L}$ & 4 \\
\hline PI 500307, 502318, 505592, 505595, 508441, 512399, 534596 & $\mathrm{~L}$ & 4 \\
\hline PI 559994, 560002, 560006, 560020, 561138, 593341, 593365 & $\mathrm{~L}$ & 4 \\
\hline PI 612459, Grif 1728 & $\mathrm{~L}$ & 4 \\
\hline Jubilee, Crimson Sweet & $\mathrm{L}$ & 3 \\
\hline Mickey Lee, Black Diamond, Sugar Baby & $\mathrm{L}$ & 4 \\
\hline
\end{tabular}

${ }^{2}$ Citrullus spp. where $\mathrm{L}=$ Citrullus lanatus var. lanatus, $\mathrm{C}=$ Citrullus lanatus var. citroides, $\mathrm{O}=$ Citrullus colocynthis, and $\mathrm{P}=$ Parecitrullus fistulosus. Mickey Lee, Jubilee, Black Diamond, and Sugar Baby are commercially available cultivars.

${ }^{y}$ Field rating is based on a 0 to 4 scale, in which $0=$ no injury observed on any of the growing terminals in the plot; 1 = very low, at least one growing terminal in the plot showing mite injury but less than $10 \%$ of the terminals showing injury; $2=$ slight injury with $\approx 25 \%$ of the terminals showing injury; $3=$ moderate injury with $\approx 50 \%$ of growing terminals showing mite injury; and $4=$ severe injury with more than $50 \%$ of the terminals showing broad mite injury.

Two C. colocynthis PIs that were rated 1 (PI 388770 , PI 386015) had relatively low mite populations compared with PI 549159, a C. lanatus var. lanatus $\mathrm{PI}$ that had $\approx 61$ broad mites but was also rated 1 . Similarly, PI 500329 , with no visible injury observed in the field, had a relatively high mite population. PI 593341, which was rated 4 in the 
field, had a relatively lower mite population compared with PI 500329. There was a significant positive correlation $\left(R^{2}=0.57, P\right.$ $=0.0054)$ between broad mite numbers on selected PIs and field ratings. It has been reported that injury symptoms can appear very rapidly on some hosts with only a few mites being sufficient to invoke economic damage (Bassett, 1981; Dhooria and Bhindra, 1977). Alternatively, it has also been observed that the deterioration of leaf and fruit quality is an important factor in reducing field populations of broad mites (Aubert et al., 1981; Gerson, 1992). Gerson (1992) noted that under optimal conditions, the broad mite populations may increase to large numbers and then rapidly decline with the depletion of food quality, weather conditions, and the presence of natural enemies. In our field trial, we did not spray acaricides for managing mites. In addition, with the availability of plants with different levels of susceptibility in the field plots, it is conceivable that mites could have quickly moved to other PIs. Echer et al. (2002), in their evaluation of pepper genotypes for resistance to broad mites, came to the conclusion that assessment of symptoms was more suitable for separating genotypes than the actual mite counts. Furthermore, in field evaluations, there is a high possibility of escape and thus we decided to evaluate these select PIs under more controlled conditions in the greenhouse to confirm their resistance.

Data from the first greenhouse experiment on seedlings of selected PIs are presented in Figure 2. Plants of 'Mickey Lee' were severely injured and had a significantly (mean rating of 7.8) higher rating than the other PIs. Jubilee had a rating of 4.8 and was lower than 'Mickey Lee'. PI 368526, PI 184800, and PI 357708 were not significantly different from 'Jubilee'. All the other PIs had significantly lower ratings than 'Mickey Lee' and 'Jubilee'. Tomczyk (1989) suggested that plant growth stage and environmental conditions influence the susceptibility or resistance of plants to spider mites. Several of the 'Mickey Lee' plants were rated 9 on the 1 to 9 scale, which was likely the result of the tender tissues being exposed to broad mite infestations. However, many of the select PIs did not have visible mite injury despite being infested at a relatively young growth stage. Resistance to whitefly in watermelon germplasm (Simmons and Levi, 2002) has been reported in several of the PIs that appeared resistant to broad mites in this study. There also are reports of broad mites being dispersed by whiteflies, indicating a phoretic relationship (Fan and Petitt, 1998; Palevsky et al., 2001). Watermelon germplasm with reported resistance to whitefly are PI 388770, PI 386015, and PI 386016 (Simmons and Levi, 2002). However, these PIs had low broad mite counts in the field and had low ratings in the experiment conducted in the Bug-Dorm where whiteflies were not present (Fig. 2). Thus, it appears that these PIs are resistant to broad mites and this
Table 3. Broad mite (Polyphagotarsonemus latus) counts from growing terminals of selected watermelon PIs grown in field plots in Charleston, SC.

\begin{tabular}{|c|c|c|c|c|}
\hline Watermelon PIs & Mite counts ${ }^{2}$ & SD & Range & Field rating $(0-4)^{\mathrm{y}}$ \\
\hline \multicolumn{5}{|c|}{ Citrullus lanatus var. lanatus } \\
\hline PI 277991 & 137.4 & 66.9 & $26-226$ & 4 \\
\hline PI 306782 & 35.8 & 19.4 & $14-61$ & 4 \\
\hline PI 593341 & 10.2 & 7.5 & $2-21$ & 4 \\
\hline PI 164685 & 34.6 & 19.1 & $7-57$ & 3 \\
\hline PI 164539 & 24.8 & 40.5 & 2-97 & 2 \\
\hline PI 549159 & 61.2 & 37.5 & $22-106$ & 1 \\
\hline PI 184800 & 5.6 & 8.8 & $0-21$ & 1 \\
\hline PI 254735 & 16.6 & 13.3 & $2-38$ & 0 \\
\hline PI 357708 & 8.8 & 3.3 & $5-13$ & 0 \\
\hline PI 368526 & 56.0 & 33.0 & $13-89$ & 0 \\
\hline PI 500329 & 70.6 & 34.8 & $21-113$ & 0 \\
\hline PI 536459 & 4.0 & 3.6 & $1-8$ & 0 \\
\hline \multicolumn{5}{|c|}{ Citrullus lanatus var. citroides } \\
\hline PI 500354 & 30.4 & 30.5 & $8-84$ & 1 \\
\hline PI 505604 & 44.8 & 41.5 & $3-92$ & 1 \\
\hline PI 532624 & 0.4 & 0.5 & $0-1$ & 0 \\
\hline \multicolumn{5}{|c|}{ Citrullus colocynthis } \\
\hline PI 388770 & 2.2 & 3.3 & $0-8$ & 1 \\
\hline PI 386015 & 1.0 & 1.2 & $0-3$ & 1 \\
\hline PI 386016 & 1.4 & 2.2 & $0-5$ & 0 \\
\hline PI 525082 & 3.6 & 4.6 & $0-11$ & 0 \\
\hline \multicolumn{5}{|c|}{ Parecitrullus fistulosus } \\
\hline PI 449332 & 16.6 & 11.5 & $3-31$ & 0 \\
\hline \multicolumn{5}{|c|}{ Citrullus lanatus var. lanatus } \\
\hline Mickey Lee & 176.1 & 156.4 & $8-448$ & 4 \\
\hline Jubilee & 177.3 & 162.9 & $7-516$ & 3 \\
\hline
\end{tabular}

$\overline{{ }^{2} \text { Broad mite counts (adults, nymphs, and eggs) are based on mites washed from } 7.62 \mathrm{~cm} \text { each of five }}$ randomly picked growing terminals.

${ }^{y}$ Field rating is based on a 0 to 4 scale, in which $0=$ no visible injury on growing terminals; $1=$ very low, at least one terminal showing signs of injury in the plot, but less than $10 \% ; 2=$ low; $3=$ medium; and $4=$ high levels of broad mite injury visible on growing terminals.

Mite injury ratings (1-9)

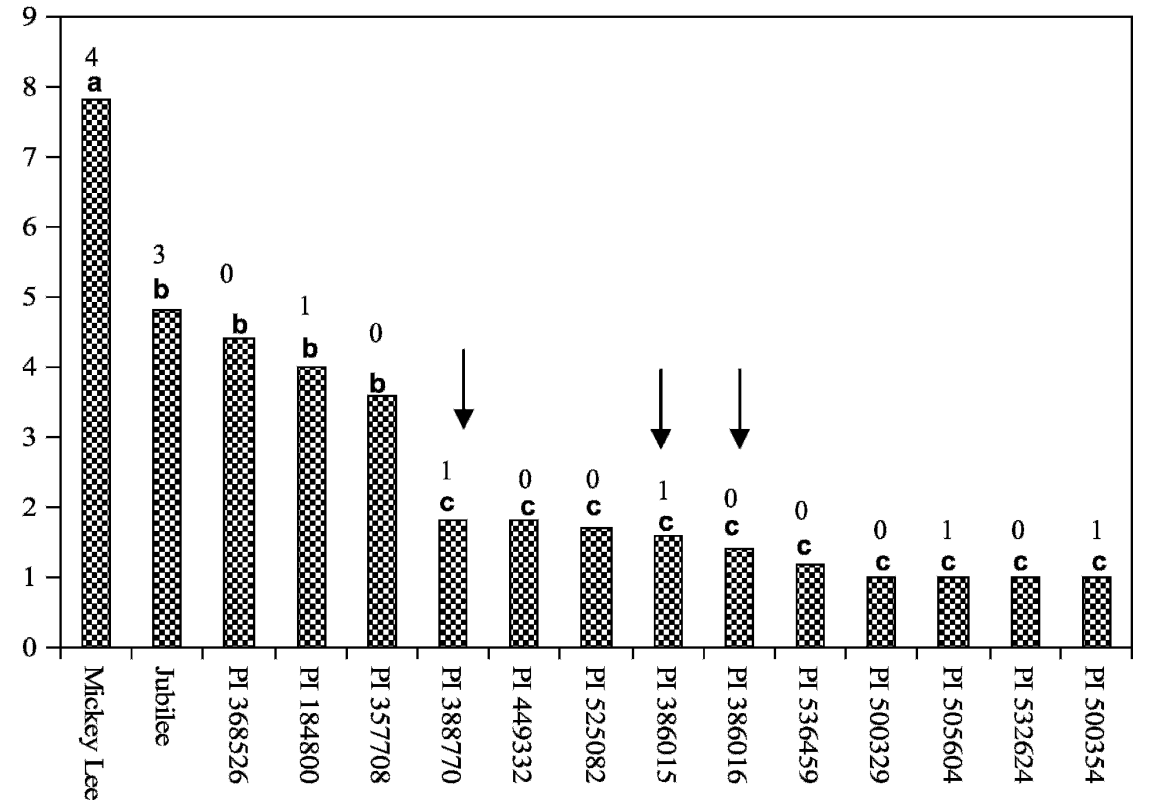

Fig. 2. Evaluation of broad mite injury on selected watermelon PIs in cages (Bug-Dorm) designed to prevent whitefly infestations. Plants were also treated with imidacloprid to prevent whitefly infestations. Mite injury rating in the Bug-Dorm is based on a 1 to 9 scale in which $1=$ no visible injury on the growing terminals and terminals lush and green and branching; $2=1 \%$ to $3 \% ; 3=4 \%$ to $10 \% ; 4$ $=11 \%$ to $25 \% ; 5=26 \%$ to $35 \% ; 6=36 \%$ to $50 \% ; 7=51 \%$ to $65 \% ; 8=$ greater than $65 \%$; and $9=$ growing terminals dead. Rating data were analyzed by arcsine transforming the midpercentage point for each rating followed by the PROC GLM procedure of SAS and mean separation tests. Bars with the same bold letter above them are not significantly different based on Waller-Duncan K-ratio $t$ test $($ K-ratio $=100)$. Arrows over bars indicate PI resistant to whiteflies (Simmons and Levi, 2002). Numbers over bars represent mite injury ratings for the same PI in the field on a 1 to 4 scale in which $0=$ no visible injury on growing terminals; $1=$ very low, at least one terminal showing signs of injury in the plot, but less than $10 \% ; 2=$ low; 3 = medium; and $4=$ high levels of broad mite injury visible on growing terminals. 
resistance is independent of the phoretic relationship of broad mites and whiteflies.

Because of the reports of a phoretic relationship between mites and whiteflies, we treated all the plants with imidacloprid and monitored all the plants closely for the presence of whitefly in the greenhouse experiments. Unlike other experiments in which the same number of larger mites (e.g., spider mites) were placed on each watermelon plant or leaf (Lopez et al., 2005; Mansour and Karchi, 1994), we placed infested growing tips because it was difficult to place the same number of broad mites on each plant because mites are much smaller. Similarly, in experiments conducted on cucumbers, an approximate number of broad mites was placed on each plant (Grinberg et al., 2005). Data from two of the greenhouse experiments are presented in Table 4. In the first experiment, we placed a relatively low number of broad mites on each plant. In this experiment, the mite population developed very rapidly on the susceptible 'Mickey Lee'. However, all other PIs had significantly lower broad mite populations. We did not observe any broad mites on some of the growing terminals of the $C$. colocynthis PI such as PI 525082 and PI 388770, PI 386015, and PI 386016.

It was difficult to separate levels of resistance when the PIs were infested with a low number of broad mites. Therefore, for the final experiment, we infested growing terminals with a much higher number of broad mites. This technique allowed us to identify good sources of resistance. We tried to time the broad mite infestations in the greenhouse with the same plant phenology that was observed in the field. Growing terminals of 'Mickey Lee' had significantly more injury and higher mite counts than many of the selected PIs. PI 536459 and PI 532624, which were rated 0 in the field, had a very high broad mite population in the greenhouse experiments. These PIs may have escaped broad mite infestation in the field, or broad mite populations and injury simply may not have yet developed when we rated the field plots. Also, greenhouse-grown plants are generally more tender than field-grown plants, which may have contributed to their susceptibility. There was a significant positive correlation between ratings of the growing terminals and broad mite populations in the second experiment. The correlation coefficient was lower in the first count $\left(R^{2}=0.47\right.$, $P=0.0001)$ compared with the second count $\left(R^{2}=0.67, P=0.0001\right)$. In previous studies, no significant correlation between broad mite numbers and levels of damage were observed on cucumbers (Grinberg et al., 2005). It also has been reported that just a few broad mites are sufficient to cause significant economic damage (Coss-Romero and Peña, 1998). It is possible that the significant correlation was attributable in part to a larger sample size and a skewed distribution of ratings toward the lower end because of many resistant PIs. Based on all experiments, PI 357708, PI 500354, PI 386015, PI386016, PI 525082, and PI 449332 can be considered as sources of resistance to broad mites. Under optimal conditions, broad mites can complete one life cycle in $\approx 1$ week (Gerson, 1992; Jones and

Table 4. Evaluation of broad mite infestation and injury on watermelon PIs in greenhouse experiments.

\begin{tabular}{|c|c|c|c|c|c|}
\hline \multirow[b]{2}{*}{ Watermelon PIs } & \multirow{2}{*}{$\begin{array}{c}\text { Expt. I } \\
\text { Broad mite } \\
\text { counts }^{z}\end{array}$} & \multicolumn{4}{|c|}{ Expt. II } \\
\hline & & $\begin{array}{l}\text { First injury } \\
\text { rating }(1-9)^{\mathrm{y}}\end{array}$ & $\begin{array}{l}\text { First broad } \\
\text { mite counts }\end{array}$ & $\begin{array}{l}\text { Second injury } \\
\text { rating }(1-9)\end{array}$ & $\begin{array}{l}\text { Second broac } \\
\text { mite counts }\end{array}$ \\
\hline \multicolumn{6}{|c|}{ Citrullus lanatus var. lanatus } \\
\hline PI 184800 & $22.6 b^{x}$ & $3.0 \mathrm{bc}$ & $779 \mathrm{ab}$ & $3.2 \mathrm{bc}$ & $524 \mathrm{ab}$ \\
\hline PI 357708 & $7.8 \mathrm{de}$ & $1.0 \mathrm{~d}$ & $25 \mathrm{~cd}$ & $1.4 \mathrm{de}$ & $31 \mathrm{c}$ \\
\hline PI 368526 & 5.6 bcde & $1.0 \mathrm{~d}$ & $62 \mathrm{bc}$ & $1.0 \mathrm{e}$ & $47 \mathrm{bc}$ \\
\hline PI 500329 & 4.0 cde & $1.0 \mathrm{~d}$ & $157 \mathrm{bc}$ & $1.6 \mathrm{cde}$ & $71 \mathrm{abc}$ \\
\hline PI 536459 & $11.8 \mathrm{bc}$ & $4.0 \mathrm{ab}$ & $1053 \mathrm{a}$ & $6.8 \mathrm{a}$ & $448 \mathrm{ab}$ \\
\hline \multicolumn{6}{|c|}{ Citrullus lanatus var. citroides } \\
\hline PI 500354 & 5.8 bcde & $1.0 \mathrm{~d}$ & $33 \mathrm{~cd}$ & $1.6 \mathrm{de}$ & $25 \mathrm{c}$ \\
\hline PI 505604 & 1.4 ef & $1.0 \mathrm{~d}$ & $4 \mathrm{e}$ & $3.0 \mathrm{bcd}$ & $103 \mathrm{abc}$ \\
\hline PI 532624 & $6.6 \mathrm{bcd}$ & $1.4 \mathrm{~d}$ & $73 \mathrm{~cd}$ & $3.6 \mathrm{~b}$ & $871 \mathrm{a}$ \\
\hline \multicolumn{6}{|c|}{ Citrullus colocynthis } \\
\hline PI 388770 & $0.9 \mathrm{f}$ & $1.0 \mathrm{~d}$ & $57 \mathrm{bc}$ & $1.6 \mathrm{de}$ & $80 \mathrm{bc}$ \\
\hline PI 386015 & 2.8 bcde & $1.8 \mathrm{~cd}$ & $92 \mathrm{c}$ & $1.0 \mathrm{e}$ & $26 \mathrm{c}$ \\
\hline PI 386016 & $1.6 \mathrm{ef}$ & $2.0 \mathrm{~cd}$ & $59 \mathrm{c}$ & $1.2 \mathrm{e}$ & $22 \mathrm{c}$ \\
\hline PI 525082 & $0.3 \mathrm{f}$ & $2.2 \mathrm{~cd}$ & $58 \mathrm{c}$ & $1.2 \mathrm{e}$ & $39 \mathrm{bc}$ \\
\hline \multicolumn{6}{|c|}{ Parecitrullus fistulosus } \\
\hline PI 449332 & $1.2 \mathrm{ef}$ & $1.0 \mathrm{~d}$ & $11 \mathrm{de}$ & $1.0 \mathrm{e}$ & $118 \mathrm{c}$ \\
\hline \multicolumn{6}{|c|}{ Citrullus lanatus var. lanatus } \\
\hline Mickey Lee & $336.8 \mathrm{a}$ & $4.6 \mathrm{a}$ & $558 \mathrm{a}$ & $4.0 \mathrm{~b}$ & $348 \mathrm{ab}$ \\
\hline Jubilee & - & $5.3 \mathrm{a}$ & $1033 \mathrm{a}$ & - & - \\
\hline
\end{tabular}

${ }^{\mathrm{z}}$ Mean counts (adults and nymphs) are based on mites washed from $5 \mathrm{~cm}$ each of five growing terminals for each PI. Expt. I was conducted on 6-week-old seedlings of the various PIs. Expt. II was initiated on 10 -week-old plants. Data were recorded for a second time (second broad mite count) on plants infested in Expt. II 15 weeks after artificial infestation. Dashes indicate no data collected.

${ }^{y}$ Broad mite injury ratings are based on a 1 to 9 scale, in which $1=$ no visible injury on the growing terminals; $2=1 \%$ to $3 \%$ injury; $3=4 \%$ to $10 \% ; 4=11 \%$ to $25 \% ; 5=26 \%$ to $35 \% ; 6=36 \%$ to $50 \% ; 7=51 \%$ to $65 \% ; 8=$ greater than $65 \%$; and $9=$ growing terminals dead. Rating data were analyzed by arcsine transforming the midpercentage point for each rating followed by PROC GLM procedure of SAS and mean separation tests.

${ }^{x}$ Means in a column followed by the same letter are not significantly different based on Waller- Duncan K-ratio $t$ test $(\mathrm{K}$-ratio $=100)$.
Brown, 1983). Thus, by the time we took the second count, the mites could have completed five to six generations. Nevertheless, several of the resistant PIs did not support large mite populations, further confirming their resistance. In the second count of the greenhouse experiment, we observed over 500 mites on one growing terminal of PI 449332 with a injury rating of 1 , but the terminals from the remaining PI 449332 plants had much lower mite populations $($ mean $=9)$; hence, this PI had a mean mite count of 118 (Table 4). PI 386015 belonging to $C$. colocynthis not only has resistance to broad mites, but also has resistance to whiteflies (Simmons and Levi, 2002) and twospotted spider mites (Lopez et al., 2005). Interestingly, all the PIs belonging to $C$. colocynthis in this study also have resistance to two-spotted spider mites (Lopez et al., 2005). Resistance to insects may be the result of the presence of toxins in C. colocynthis PI (El-Naggar et al., 1989). Similarly, it was suggested that resistance to carmine mites in the cucurbit Lagenaria was the result of some resistance-promoting substance that was transported to the leaves (Edelstein et al., 2000). The density of glandular leaf hairs has been suggested as a mechanism of resistance to broad mites in potatoes (Gibson and Valencia, 1978). Leaves of C. colocynthis PIs were reported to have a higher density of trichome compared with the other Citrullus spp. (Simmons and Levi, 2002). However, we did not assess trichome density among the resistant and susceptible PIs in this study. Based on previous studies (Levi et al., 2002; Simmons and Levi, 2002), it may be possible to transfer the resistance from C. colocynthis PIs to cultivated watermelon types. In our study, PI 500354 (C. lanatus var. citroides) had a good level of resistance to broad mites; however, it was reported to be highly susceptible to two-spotted spider mites (Lopez et al., 2005). Thus, the genes controlling resistance to broad mites and spider mites may be different. We also identified PI 357708 and PI 368526 belonging to $C$. lanatus var. lanatus as potential sources of resistance to broad mites. From a breeding perspective, it may be easier to transfer resistance genes from $C$. lanatus var. lanatus PI to commercial watermelon hybrids. Further studies will be needed to determine the inheritance and mechanisms of resistance to develop commercially acceptable watermelon genotypes with resistance to insect and arthropod pests.

\section{Literature Cited}

Aubert, B., P. Lossois, and J. Marchal. 1981. Mise en évidence des degates causes par Polyphagotarsonemus latus (Banks) sur parayers a l'ile de la Reunion. Fruits 36:9-24.

Bassett, P. 1981. Observations on broad mite Polyphagotarsonemus latus (Banks) (Acari: Tarsonemidae) attacking cucumber. Proc. Br. Crop Prot. Conf. Pests Dis. 1:99-103.

Cividanes, F.J., M.J. Thomazini, and L.G.C. Santos. 1987. Distribuicão do ácaro branco Polyphagotarsonemus latus (Banks, 1904) (Acari: 
Tarsonemidae) em plantas de algodã. An. Soc. Entomol Bras. 16:93-104.

Coss-Romero, M.de and Peña, J.E. 1998. Relationship of broad mite (Acari: Tarsonemidae) to host phenology and injury levels in Capsicum annuum. Fl. Entomol. 81:515-526.

Dhooria, M.S. and O.S. Bhindra. 1977. Polyphagotarsonemus latus (Banks) a mite pest of chilli and potato in Punjab. Acarol. Newsl. 4:7-9.

Dhooria, M.S., D. Singh, B.S. Shukla, and G.S. Bhathol. 1987. Differential response of watermelon accessions for resistance to red spider mite, Tetranychus cinnabarinus (Boisduval). J. Punjab Agr. Univ. 24:590-594.

Echer, M.M., M.C.A. Fernandes, and R.L.D. Ribeiro. 2002. Evaluation of Capsicum genotypes for resistance to broad mite. Hort. Bras. 20:217-221.

Edelstein, M., Y. Tadmor, F. Abo-Moch, Z. Karchi, and F. Mansour. 2000. The potential of Lagenaria rootstock to confer resistance to the carmine spider mite, Tetranchus cinnabarinus (Acari: Tetranychidae) in Cucurbitaceae. Bull. Entomol. Res. 90:113-117.

El-Naggar, M.E., M.M. Abdel-Sattar, and S.S. Mosallam. 1989. Toxicity of colocynithin and hydrated colocynithin from alcohol extract of Citrullus colocynthis pulp. J. Egypt. Soc. Parasitol. 1:179-185.

Fan, Y. and F.L. Petitt. 1998. Dispersal of the broad mite, Polyphagotarsonemus latus (Banks) (Acari: Tarsonemidae) on Bemisis argentifolii (Homoptera: Aleyrodidae). Exp. Appl. Acarol. 22:411-415.

Gerson, U. 1992. Biology and control of the broad mite, Polyphagotarsonemus latus (Banks) (Acari: Tarsonemidae). Exp. Appl. Acarol. 13:163-178.

Gibson, R.W. and L. Valencia. 1978. A survey of potato species for resistance to the mite Polyphagotarsonemus latus with particular reference to the protection of Solanum berthaultii and $S$. tarijense by glandular hairs. Potato Res. 21:217-223.

Goff, M.L. 1987. A catalog of the Acari of the Hawaiian Islands. Univ. Hawaii, Res. Ext. Ser. No. 075.

Grinberg, M., R. Perl-Treves, E. Palevsky, I. Shomer, and V. Soroker. 2005. Interaction between cucumber plants and the broad mite, Polyphagotarsonemus latus: From damage to defense gene expression. Entomol. Exp. Appl. 115:135-144.

Jones, V.P. 1988. Status of the broad mite (Polyphagotarsonemus latus) (Banks) - A threat to the vegetable fruit and ornamental industry of Trinidad. Proc. 2nd Ann. NIHERST Seminar, Trinidad.

Jones, V.P. and R.D. Brown. 1983. Reproductive responses of the broad mite Polyphagotarsonemus latus (Acari: Tarsonemidae), to constant temperature-humidity regimes. Ann. Entomol. Soc. Amer. 76:466-469.

Lazarre, M. and D. Gerling. 1993. The population dynamics of natural enemies of Bemisia tabaci in cotton fields and the influence of insecticide sprays. Phytoparasitica 21:171-172.

Levi, A., C.E. Thomas, T. Joobeur, X. Zhang, and A. Davis. 2002. A genetic linkage map for watermelon derived from a test cross population: (Citrullus lanatus var. citroides $\times$ Citrullus lanatus var. lanatus $) \times$ Citrullus colocynthis. Theor. Appl. Genet. 105:555-563.

Lindquist, E.E. 1986. The world genera of Tarsonemidae (Acari:Heterostigmata): A morphological, phylogenetic, and systematic revision, with a reclassification of family-group taxa in the Heterostigmata. Mem. Entomol. Soc. Can 136:1-517.

Lopez, R., A. Levi, B.M. Shepard, A.M. Simmons, and D.M. Jackson. 2005. Sources of resistance to two-spotted spider mite (Acari: Tetranychidae) in Citrullus spp. HortScience 40:16611663.
Mansour, F. and Z. Karchi. 1994. Resistance to carmine spider mite in watermelon. Phytoparasitica 22:43-45.

Palevsky, E., V. Soroker, P. Weintraub, F. Mansour, F. Abo-Moch, and U. Gerson. 2001. How species-specific is the phoretic relationship between the broad mite, Polyphagotarsonemus latus (Banks) (Acari: Tarsonemidae), and its insect hosts? Exp. Appl. Acarol. 25:217-224.

Sanders, D.C. 2005. Vegetable crop guidelines for the Southeastern U.S. North Carolina Vegetable Growers Association.

Simmons, A.M. and D.M. Jackson. 2000. Evaluation of foliar applied insecticides on abundance of parasitoids of Bemisia argentifolii (Homoptera: Aleyrodidae) in vegetables. J. Entomol. Sci. 35:1-8.

Simmons, A.M. and A. Levi. 2002. Sources of whitefly (Homoptera:Aleyrodidae) resistance in Citrullus for the improvement of cultivated watermelon. HortScience 37:581-584.

Tomczyk, A. 1989. Physiological and chemical responses of different host plants to infestations by spider mites (Acarina:Tetranychidae). Warsaw Agric. Univ. Press, Warsaw, Poland.

Tulisalo, U. 1972. Resistance to the two-spotted spider mite, Tetranychus urticae Koch (Acarina, Tetranychidae) in the genera Cucumis and Citrullus (Cucurbitaceae). Annals Entomol. Fennici 38:60-64.

U.S. Department of Agriculture. 2006. Agricultural Statistics Board. Vegetables 2005 summary. USDA Natl. Agr. Stat. Serv., Washington, DC. Oct. 2006. <http://www.nass.usda.gov>.

Webb, S.E., D.G. Riley, and G.E. Brust. 2001. Insect and mite pests, p. 131-149. In D.N. Maynard (ed.). Watermelons. Characteristics, production, and marketing. ASHS Press, Alexandria, VA.

Zhang, Z.-Q. 2003. Mites of greenhouses, identification, biology and control. CABI Publ. Internat., Wallingford, UK. 